\title{
小児期に腎移植を受け，成人年齢に達した 症例の社会生活について
}

\author{
後藤 芳充 ·田中 一樹 - 畔柳 佳幸 - 松隈 英治 - 山田 拓司 \\ (受付日: 平成 22 年 7 月 30 日 採用日 : 平成22年 9 月 9 日)
}

\section{要旨}

腎不全医療を行っているわれわれの最終目標は，患児 を一般の社会人として自立させることにある。腎代替療 法の一つである腎移植医療の進歩はその目標を容易にし た。われわれは1987年より腎移植を行っており，19歳以 上で当院外来でフォローを行っている患者は24例いる。 そのうち，仕事を持たずに自宅で生活している患者は， うつ病で精神科医に受診している1例たけであった。学 生を除いた就職年齢の患者は17例であり，失業率は $5.8 \%$ となり, 同年齢の完全失業率が $6.4 \sim 9.4 \%$ あるる ことから比べ，遜色のない就業率であった。何らかの資 格を持っている症例 5 例は, 全例その資格に関する職業

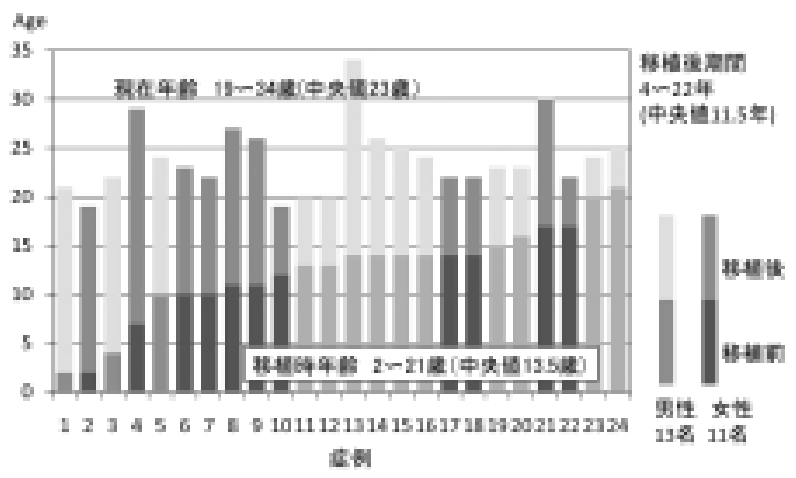

図 1 患者profile〈年齢〉

名古屋第二赤十字病院腎臟病総合医療センター小览科 （厂466-8650 名古屋市昭和区妙見町2-9）

The social life of patients performed renal transplant for childhood

Yoshimitsu Gotoh, Kazuki Tanaka, Yoshiyuki Kuroyanagi, Eiji Matsukuma, Takuji Yamada

Nagoya Daini Red Cross Hospital. Kidney Center Pediatrics
に就いていた。 4 名は結婚しており，男性の 2 名は父親 となっている。腎移植は確立した医療であるとともに， 社会生活についても有用である。

\section{序言}

小児の慢性腎不全医療を行っているわれわれの最終目 標は，患児を一般の社会人として自立させることにあ る。腎代替療法の一つである腎移植医療の進歩はその目 標達成を容易にした。われわれは1987年より小児の腎移 植を行って抢り，成人年齢に達した症例も多くなってき た。それらの症例に対し，成年後の社会生活に関しての 検討を行った。

\section{対象・方法}

小児期に当院で腎移植を行い，当院の小児腎移植外来 でフォローアップしている19歳以上（高校卒業後）の患

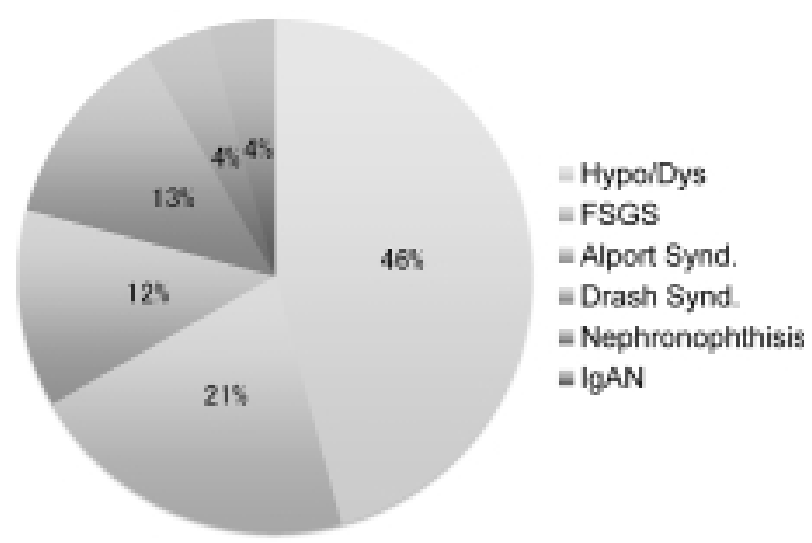

図 2 患者 profile〈基礎疾患〉

Key words：小児腎移植 社会生活

就職

結婚

自立 


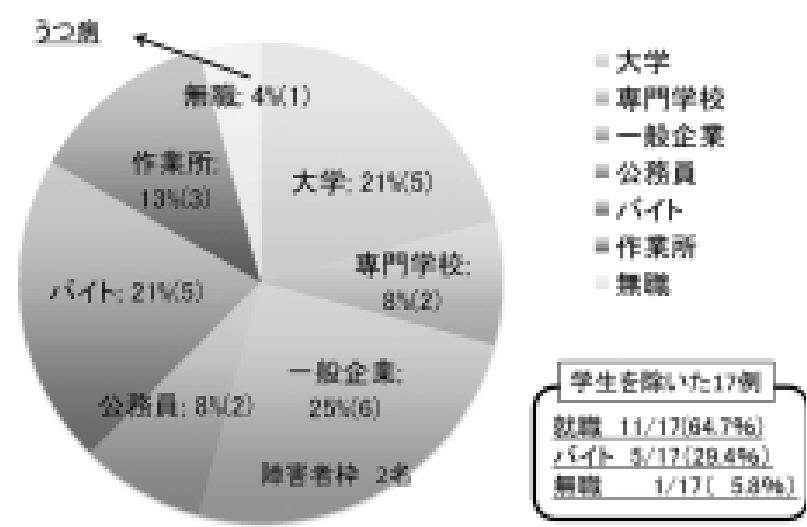

図 3 学業·就業状況

者24例を対象にした。

学業, 就職状況, 結婚, 妊娠, 挙児について調べた。

\section{成 績}

対象となった患者のうちわけは，男性13例，女性11例 で, 移植時年齢 $2 \sim 21$ 歳 (中央值13.5歳)，移植後期間 $4 \sim 22$ 年 (中央值11.5年), 現在の年齢19３4歳（中央 值23歳）であった（図 1 )。原疾患は図 2 にあらわした ように，低形成異形成腎が46\%，巣状系球体硬化症が $21 \%$ ，アルポート症候群が $12 \%$, Denys Drash 症候群が 13\%，ネフロン疾，IgA 腎症が各 1 例であり，一般的な 日本人の小児腎不全の疾患割合と同様であった

学業については, 大学生が 5 例, 専門学校生が 2 例で あった。就業状況では，一般企業に就職しているのが6 例であり，そのうち障害者枠で就業している人が 2 例で あった。その他，公務員が 2 例，バイトが 5 例，作業所 に通所しているのが 3 例で，無職であったのが 1 例のみ であった。無職の 1 例はうつ病で，精神科に受診をして いる症例であった。学生を除いた17例で割合を検討する と, 就職が $64.7 \%$, バイトが $29.4 \%$, 無職が5.8\%で あった（図 3 )。

資格を持っている人が 5 例あり，薬剤師が 2 例，調理 師，栄養士，美容師が各 1 例であり，全例それに関係す る仕事に就いていた。

4 例は結婚しており, 男性が 2 例，女性が 2 例であっ た。1例は妊娠したが，妊娠継続中に胎内死亡した。男 性 2 名に子どもが生まれ，父親となっていた。

\section{考察}

当院でフォローアップしている就業年齢に達している 患者 17 名のうち，作業所やバイトを含めれば無職なのは 1 例のみで $5.8 \%$ であった2010年 4 月の総務省発表の

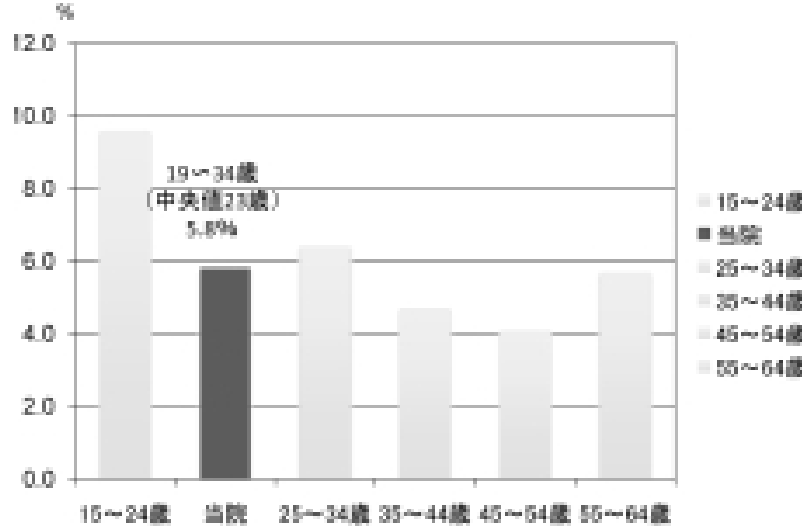

図 4 年齢別完全失業率と当院症例との比較

(2010年 4 月 総務省発表)

年齢別完全失業率によると，15～24歳が9.4\%，25～34 歳は $6.4 \%$ であり，当院の年齢層は $19 \sim 34$ 歳でお扮よそ この年齢分布に当てはまり，5.8\%というのは非常に良 い就業率である（図4）。しかし，個別的に見れば，職 場やバイトを何回も変える例や，就職をするのに数年か けている例もある。ただ，自分で仕事やバイト先を苦労 しながらもなんとか仕事を見つけていること自体，自立 しているということだと思われる。

一般企業に就職している 6 例のうち 2 例は障害者枠で 就職しているが，公務員を入れて 8 例中 6 名は一般枠で ある。腎移植患者は, 月 1 回程度の通院を除けば, 健常 者とほとんど変わりない就業ができるのにもかかわら ず，『障害者 1 級』というレッテルにより企業から敬遠 されている面もある。障害者雇用促進法では一定規模以 上の事業主は障害者を一定割合以上雇用する義務があ り，腎移植患者の『障害者 1 級』は企業にとっては『有 利』だと思うのだが，腎移植患者の状態がまだ一般に知 られていないことが大きな原因と思われる。

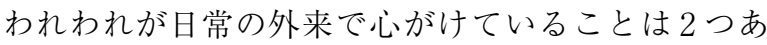
る。1つめが腎障害以外に障害を持っていない場合は, 普通の学校に行ってもらうようにしていることである。 つまり腹膜透析をやっていてもできるだけ一般の子ども の中に混じって生活をしてもらっている。今回の 24 例の 中でそのためにいじめを受けた，学校を休みがちになっ た，不登校になった等の訴えは聞かれなかった。ただ， うつ病で就業できていない患児は基礎疾患がアルポート 症候群で, 難聴が現在の状況に影響しているかもしれな い。2つ目は高校や大学の進路を決める時に，『手に 職』をつけることを勧めるということである。薬剤師, 栄養士，調理師，美容師の資格を持った人たちは全例資 格に関する職業に就いている。このように，小さな頃か 


\section{腎移植後妊娠基準}

1 . 移植後 2 年間全身状態良好

2 . 移植腎機能が安定 $[\mathrm{Cr}<2 \mathrm{mg} / \mathrm{d} \ell,<1.5 \mathrm{mg} / \mathrm{d} \ell$ 以下が望ま しい]

3．急性拒絶が最近ない，または拒絶を思わせるものがない

4.血圧正常または，降圧剤が少量（1剂のみ）

5 . 蛋白尿がないか, 少量 $[<0.50 \mathrm{~g} / \mathrm{day}]$

6. 移植腎がエコー上正常 [腎杯の拡張がない]

7 . 推奨される免疫抑制剤

1) $\mathrm{PSL}<15 \mathrm{mg} /$ day

2) $\mathrm{Az} \leqq 2 \mathrm{mg} / \mathrm{kg} / \mathrm{day}$

3 ) Csor Tac 治療域レベル

4) MMF or sirolimus 禁忌

5 ) MMF or sirolimus は妊娠 6 週間前に中止すべきである

Nephrol. Dial. Transplant., 17 (supple4) 50 - 55, 20034) を改変

ら一般の子どもたちと変わらない生活をしてもらうこと で，同世代の人と切碰玩磨し，自然と自立につながった ものと思われる。

一方，今回の検討の中には発達に遅れのある症例が 3 例いるが，現在も移植腎機能は良好で作業所に入所して 働いている。これらの症例はいずれも低形成異形成腎 で，小学生や中学生の頃から特別支援学級に入ってお り，社会生活に適応できるように訓練がなされ，就職時 には作業所などの斡旋もされ，当方が困ることはなかっ た。

最近の移植患児の社会復帰については，Broyer ら ${ }^{2)}$ が，73\%の症例が就職しており，一般の同世代の人たち と変わらなかったと報告している。Kärrfelt らは，就職 していたのは $86 \%$ で一般よりやや劣ったが，これは年齢 が若く，学生が多かったためとしている。さらにQOL をスコア化し，中央值が10点中8.0であり，移植後の心 理社会的状況は非常によいと結論づけている3)。前者が フランス，後者がスウェーデンの報告であり，国による 事情が違っていても，当院と同様，小览期に腎移植を 行った患児の成人後の社会生活は良好であると考えられ る。

結婚については，当院では男女 2 名ずつ 4 名が結婚し ていた。2 名の男性は子どもがいるが，女性の 2 名には 子どもがいない。1名は妊娠したが，妊娠継続中に胎内 死亡した。この女性は腎機能が妊娠にとってぎりぎりの 状態であり，妊娠継続により移植腎廃絶の可能性を示唆 され，現在は挙児の希望はしていない。もう1名の女性 は挙児を希望しているが，幼少期の腹部手術による腹腔 内の癒着により，妊娠を継続することは無理であろうと 産科には指摘されている。腎移植患者が内服している免 疫抑制剂や降圧剂には妊娠に禁忌の薬があり, 結婚の有
無にかかわらず，妊娠可能な年齢となった女性の腎移植 患者には伝えておく必要がある。表はヨーロッパで使用 されている腎移植後妊娠基準 が，日本でもこの基準に準拠している。これによると， 免疫抑制剂はステロイドやアザチオプリン，治療域レベ ルのカルシニューリンインヒビターは妊娠中も投与可能 であるが，ミコフェニール酸モティフィル（MMF）や シロリムスは禁忌となっている(表)。降圧剤は移植患 者にもよく使用されるアンギオテンシン変換酵素阻害剤

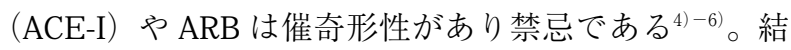
婚や妊娠の問題は小览科医には苦手な分野ではあるが, 青年期の女性腎移植患者を診る場合, 最低限の知識は 持っておく必要がある。腎移植患者の妊娠出産について の報告はたくさんある。それらをまとめると妊娠期に高 血圧になることが多く，分婏は帝王切開が多く，子ども は早産で低出生体重児が多いが，多発奇形等の先天異常 の率は一般の出産と变わらない。妊娠前の移植腎機能や 全身状態がよければ，急性拒絶は増えることはなく，そ の後の移植腎機能障害となることも少なく，管理をうま く行えば妊娠出産の成績は良好である7)-9)。しかし，小 児の腎不全患者は先天性疾患が多く ${ }^{1)}$, 泌尿生殖器の奇 形が合併していることも多く，妊娠出産に障害が出ると 思われるが，このようなことは上記文献からは推測でき ず，さらに検討が必要と思われる。

小児期に腎移植を行った患児の成人後の社会生活は良 好であると考えられ，その意味でも腎移植医療は確立さ れたものである。たた，当院の症例は 24 例と少ないこと と，社会の受け入れ態勢に地域差もあると考えられるた め,このような検討がさらに行われることが期待され る。

\section{結 論}

小児期に腎移植を行い，成人年齢に達した患児の社会 生活について検討した。就職年齢に達している17名のう ち無職なのは 1 名のみであり, 一般の完全失業率から考 えて，遜色のない率であった。4名結婚しており，男性 の 2 名は父親となっていた。腎移植により社会的な自立 は可能になっていると考えられた。

なお，本論文の要旨は第45回日本小児腎臓病学会 （2010年 7 月 3 日）にて発表し, 優秀演題論文として投 稿の依頼を受けた論文である。

「日本小児腎臓病学会の定める基準に基づく利益に関す る開示事項はありません。」 


\section{文献}

1 ) 本田雅敬 : 腹膜透析治療の現況一2001. 小児 PD 研究会雑誌 $16: 44-49,2003$.

2 ) Broyer, M., Le Bihan, C., Charbit, M., Guest, G., Tête, M. J., Gagnadoux, M. F., Niaudet, P.: Long-term social outcome of children after kidney transplantation. Transplantation 77 : 1033-1037, 2004.

3 ) Kärrfelt, HME ., Berg, UB. : Long-term psychosocial outcome after renal transplantation during childhood. Pediatr Transplantation $12: 557-562,2008$.

4 ) European Best Practice Guidelines for Renal Transplantation (Part 2) IV. 10 Pregnancy in renal transplant recipients Guidelines. Nephrol. Dial. Transplant. 17 (supple 4) 50-55, 2002.

5 ) Lessan-Pezeshki, M.: Pregnancy after renal transplantation: points to consider. Nephrol. Dial. Transplant. 17:703-707,
2002.

6 ) Sekine, T., Miura, K., Takahashi, K., Igarashi, T. : Childeren's toxicology from bench to bed-Drug-induced renal injury (19: The toxic effects of ARB/ACEI on fetal kidney development. J Toxicol Sci. 34 : SP245-50, 2009.

7 ) Kainz, A., Harabacz, I., Cowlrick, I. S., Gadgil, S. D., Hagiwara, D. : Review of the course and outcome of 100 pregnancies in 84 women treated with tacrolimus. Transplantation. $70: 1718$ 1721,2000

8 ) Byrd, L., Donnai, P., Gokal, R. : Outcome of pregnancy following renal transplantation. J Obstet Gynaecol. 20 : 15-118, 2000.

9 ) Al. Duraihimh, H., Ghamdi, G., Moussa, D., Shaheen, F. Mohsen, N., Sharma, U., Stephan, A., Alfie, A., Alamin, M., Haberal, M., Saeed, B., Kechrid, M., Al-Sayyari, A. : Outcome of 234 pregnancies in 140 renal transplant recipients from five middle eastern countries. Transplantation. $85: 840-843,2008$.

The social life of patients performed renal transplant for childhood

Nagoya Daini Red Cross Hospital. Kidney Center Pediatrics

Yoshimitsu Gotoh, Kazuki Tanaka, Yoshiyuki Kuroyanagi, Eiji Matsukuma, Takuji Yamada

With the recent advances in renal transplantation, one of the kidney substitution therapies, the majority of our patients have successfully achieved our goal, living independently their lives similar to the "healthy" people.

At our institution, we stated renal transplantations in 1987. To date, there are 24 patients aged over 19 who have been followed up since childhood.

Only one out of them, who requires psychiatric care for depression, spends most of the time at home without working. The jobless rate for 17 patients who graduated from schools is $5.8 \%$. We regard this result acceptable since the complete unemployment ratio for the entire population of this age group is reported $6.4-9.4 \%$. Five patients have obtained some qualifications/licenses for occupation and their works are related to them. Four patients are married, including 2 males as fathers. Renal transplantation for children and adolescents have established medical care and promotes better social activities for the patients with chronic renal insufficiency.

Key words : pediatric renal transplantation, independence, employment, marriage, social life 